\title{
Profitabilitas, Likuiditas, Leverage, Arus Kas Operasi dan Return Saham Syariah pada Perusahaan Jakarta Islamic Index
}

\author{
Sinta Wardani ${ }^{1}$, Hermiyetti $^{2}$, Muhammad Yusuf ${ }^{3}$ \\ ${ }^{1}$ Universitas Pancasila, Jl. Srengseng Sawah, Jagakarsa, Jakarta Selatan, 12640 \\ ${ }^{2}$ Universitas Bakrie, Jl. HR. Rasuna Said Kavling C-22, Kuningan, Jakarta Selatan \\ ${ }^{3}$ Indonesia Banking School, Jl. Kemang Raya No. 35, Kemang Raya, Jakarta Selatan 12730
}

INFO ARTIKEL

\section{JEL Classsification:}

R53

Keywords:

profitability, liquidity, leverage, operating cash flow and sharia stock returns.

\section{$A B S T R A C T$}

This study aims to analyze and believe the factors that affect the return of sharia in the Jakarta Islamic Index. The sample of research is 29 companies with data from 2009-2015. Data analysis using multiple regression analysis. The results showed, liquidity and leverage is not significant significant to the return of sharia stocks. Operating cash flows are significant and positive against Sharia share returns. An interesting finding in this research is the role of operating cash flow as a determinant of stock returns. Future research can be proven the role of cash flow and other financial performance as a determinant of stock returns.

\begin{abstract}
A B S T R A K
Penelitian ini bertujuan untuk menganalisis dan menguji secara empiris mengenai faktor-faktor yang mempengaruhi return saham syariah di Jakarta Islamic Index. Sampel penelitian sebanyak 29 perusahaan dengan data tahun 2009-2015. Analisis data menggunakan analisis regresi berganda. Hasil penelitian menunjukkan bahwa profitabilitas. likuiditas dan leverage tidak berpengaruh signifikan terhadap return saham syariah. Arus kas operasi berpengaruh signifikan dan positif terhadap return saham syariah. Temuan menarik dalam penelitian ini adalah peran arus kas operasi sebagai penentu return saham. Penelitian mendatang dapat dibuktikan peran arus kas investasi dan pendanaan serta kinerja keuangan lainnya sebagai penentu return saham.
\end{abstract}

\section{Pendahuluan}

Keberadaan Pasar Modal dalam hal ini Bursa Efek Indonesi (BEI) memberikan alternatif kepada masyarakat untuk berinvestasi, investasi sendiri sebenarnya dapat dibagi menjadi investasi pada sektor riil dengan membeli asset berwujud berupa tanah, gedung dan kendaraan dan investasi pada sektor keuangan melalui aktivitas jual beli saham, obligasi dan surat berharga lainnya. Masing-masing jenis investasi yang mengharapkan return tentu memiliki resiko yang berbeda-beda, pada investasi sektor riil resiko yang dihadapi bisa berupa tingginya

*Email Korespondensi: ${ }^{1}$ sintawardani49@yahoo.com, 2hermi_yetti@yahoo.com, ${ }^{3}$ moch.yusuf@ibs.ac.id 
biaya pemeliharaan sedangkan resiko investasi pada sektor keuangan adalah instabilitas perekonomian dan ketidakpastian peraturan dan perundang-undangan. Pada investasi sektor keuangan khususnya yang terjadi pada aktifitas di Bursa Efek Indonesia, resiko dapat diminimalisir dengan cara melakukan pembelian saham secara portofolio. Hal ini memungkinkan karena Bursa Efek Indonesia memberikan kesempatan seluas-luasnya kepada investor untuk melakukan pembelian beberapa jenis saham dengan menyajikan informasi-informasi keuangan yang akurat tentang saham tersebut (Hanif, 2012).

Pasar modal merupakan tempat bertemunya penawaran dan permintaan sekuritas jangka panjang. Penawaran dilakukan oleh perusahaan yang mendaftarkan perusahaannya ke Bursa Efek Indonesia, sedangkan permintaan dilakukan oleh investor yang berperan sebagai pelaku utama karena menyediakan dan memasok dana ke pasar modal. Namun, saat ini masih belum banyak masyarakat yang ingin melakukan investasi ke pasar modal karena memiliki anggapan bahwa berinvestasi ke pasar modal adalah judi. Oleh sebab itu muncullah new trend's demand yang membutuhkan keterbukaan dan transparansi pasar serta adanya pasar yang fair dan produk yang mampu menjawabnya adalah Islamic product (Nafik, 2009).

Untuk memperoleh hasil yang diharapkan maka terdapat berbagai faktor yang mempengaruhi pengambilan keputusan investasi oleh investor dan salah satunya adalah faktor rasional. Penggunaan faktor-faktor rasional sebagai dasar pengambilan keputusan investasi syariah sangat penting dilakukan karena dapat menghindarkan investor dari spekulasi. Hal tersebut dilakukan dengan senantiasa mendasarkan setiap keputusan investasi yang diambilnya, dengan dasar informasi yang relevan seperti informasi kinerja perusahaan maupun karakteristik perusahaan sehingga fluktuasi harga yang ada dapat mencerminkan kondisi emiten dan perusahaan yang sebenarnya.

Rasio keuangan menjadi salah satu faktor yang perlu dipertimbangkan oleh investor sebelum memutuskan pembelian saham, rasio keuangan suatu perusahaan dapat berubahubah dari waktu ke waktu. Demikian pula yg terjadi pada perusahaan yang tergabung dalam Jakarta Islamic Index. Berikut berisi rata-rata profitabilitas, likuiditas, arus kas operasi dan return saham dari perusahaan yang tergabung di Jakarta Islamic Index pada periode 2009-2014.

Tabel 1. Rasio Keuangan pada Perusahaan yang Tergabung di JII Periode 2009-2015

\begin{tabular}{lccccc}
\hline TAHUN & ROE & CR & LVR & CFO & RS \\
\hline 2009 & 0,35 & 3,64 & 0,83 & 3.940 .038 & 2,10 \\
2010 & 0,33 & 2,85 & 0,57 & 3.404 .372 & 0,92 \\
2011 & 0,38 & 2,94 & 0,66 & 4.372 .840 & 0,13 \\
2012 & 0,39 & 2,65 & 0,74 & 5.125 .014 & 0,34 \\
2013 & 0,37 & 2,60 & 0,81 & 4.250 .046 & 0,02 \\
2014 & 0,34 & 2,37 & 0,83 & 6.406 .153 & 0,14 \\
2015 & 0,15 & 2,24 & 1,04 & 5.085 .093 & $-0,20$ \\
\hline
\end{tabular}

Sumber : Idx Statistics Index, idx.co.id

Dengan memperhatikan tabel $1.1 \mathrm{di}$ atas terlihat bahwa selama kurun waktu 2009 - 2014, ternyata terjadi rasio keuangan yang berfluktuasi pada perusahaan yang tergabung di di Jakarta
Islamic Index. Secara khusus, ROE berfluktuasi menaik dan menurun sedangkan $\mathrm{CR}$ memiliki kecenderungan menurun selama periode 2009 - 2014. Sedangkan LVR memperlihatkan 
kecenderungan yang menurun pada tahun 2010 untuk selanjutnya menunjukkan kecenderungan menaik pada 2010 - 2014. Kondisi berfluktuasi yang menurun dan meningkat juga diperlihatkan pada CFO, sedangkan RS memperlihatkan kecenderungan yang juga berfluktuasi menurun secara tajam sampai dengan 2012, serta menaik pada 2013 dan menurun lagi pada tahun 2014.

Tujuan penelitian ini untuk mengetahui, menguji, membuktikan dan menganalisis bahwa profitabilitas, likuiditas, leverage dan arus kas operasi secara parsial maupun silmultan berpengaruh terhadap return saham syariah. Hasil penelitian ini diharapkan bisa memberikan kontribusi baik langsung maupun tidak langsung. Secara praktis diharapkan penelitian ini bisa memberikan wawasan pengetahuan tentang segala aspek keuangan dan akuntansi perusahaan agar dapat lebih mudah membuat strategi-strategi perusahaan khususnya di bidang akuntansi dan keuangan. Hasil penelitian ini juga diharapkan dapat memberikan wawasan pengetahuan dan penelitian di bidang akuntansi dan keuangan dan sebagai referensi bagi penelitian sejenis yang meneliti lebih mendalam di bidang akuntansi dan keuangan. Variabel debt to equity ratio dan working capital terbukti berpengaruh signifikan terhadap stock Return.

\section{Telaah Teori dan Pengembangan Hipotesis}

Jensen dan Meckling (1976) pertama kali menemukan teori keagenan (agency theory), yang menyatakan bahwa antara pemilik dan manajemen mempunyai kepentingan yang berbeda. Prinsip utama teori ini menyatakan adanya hubungan kerja antara pihak yang memberi wewenang (prinsipal), yaitu pemilik dengan pihak yang menerima wewenang (agent), yaitu manajer. Asumsi dasar teori agensi adalah setiap individu baik prinsipal maupun agent berusaha untuk melakukan segala sesuatu secara maksimal untuk mengoptimalkan kepentingannya sendiri-sendiri. Pihak prinsipal termotivasi untuk pengembalian sebesar- besarnya dan secepatnya atas investasi yang telah dilakukannya melalui kinerja keuangan perusahaan yang pada umumnya diharapkan selalu meningkat.

Hartono (2011: 143), menyatakan bahwa harga saham merupakan harga yang terjadi di pasar bursa pada saat tertentu dan harga saham tersebut ditentukan oleh pelaku pasar. Tinggi rendahnya harga saham ini ditentukan oleh permintaan dan penawaran saham tersebut di pasar modal. Menurut Darmadji 2011: 102), menyatakan bahwa: "Harga yang terjadi di bursa pada waktu tertentu. Harga saham bisa berubah naik atau pun turun dalam hitungan waktu yang begitu cepat. Ia dapat berubah dalam hitungan menit bahkan dapat berubah dalam hitungan detik. Hal tersebut dimungkinkan karena tergantung dengan permintaan dan penawaran antara pembeli saham dengan penjual saham.

Tujuan utama pelaku pasar modal dalam melakukan investasi saham di pasar modal adalah untuk memaksimalkan return. Return suatu saham biasanya tercermin dari harga saham suatu perusahaan, dimana pengertian return adalah hasil yang diperoleh dari suatu investasi. Return saham merupakan hasil keseluruhan yang diperoleh dari investasi selama periode tertentu, dan dapat digunakan sebagai salah satu tolak ukur kinerja perusahaan. Jogiyanto (2003 : 110) membedakan return saham menjadi dua jenis yaitu return realisasi (realized return) dan return ekspektasi (expected return).

Definisi pasar modal sesuai dengan Undang-undang Nomor 8 Tahun 1995 tentang Pasar Modal (UUPM) adalah kegiatan yang bersangkutan dengan Penawaran Umum dan perdagangan Efek, Perusahaan Publik yang berkaitan dengan Efek yang diterbitkannya, serta lembaga dan profesi yang berkaitan dengan Efek. Menurut Soemitra (2009 : 138) saham syariah merupakan surat berharga yang merepresentasikan penyertaan modal ke dalam suatu perusahaan. Saham dikategorikan menjadi dua yaitu saham syariah dan saham non syariah. Perbedaan ini terletak pada kegiatan usaha 
dan tujuannya. Menurut Auliyah dan Hamzah (2006), saham syariah adalah saham-saham yang memiliki karakteristik sesuai dengan syariah Islam atau yang lebih dikenal dengan sharia compliant.

Rasio keuangan, berguna untuk mengidentifikasikan beberapa kelemahan dan kekuatan keuangan perusahaan. Rasio tersebut memberikan dua cara, bagaimana membuat perbandingan dan data keuangan perusahaan yang berarti: (1) dapat meneliti rasio antarwaktu (katakanlah, untuk 5 tahun terakhir) untuk meneliti arah pergerakannya; dan (2) dapat membandingkan rasio perusahaan dengan perusahaan lainnya (Keown et al, 2004: 70).

Penelitian sejenis yang pernah dilakukan oleh peneliti sebelumnya antara lain oleh Khairi (2012), Martani dan Khairuniza (2009), Büyüksalvarc dan Abdioglu (2010) dan Nakhaei (2013) Penelitian ini menemukan bahwa variabel karakteristik perusahaan yang berpengaruh adalah Price Earning Ratio (PER) dan Long-term Debt to Capitalization Ratio sedangkan variabel Dividend Payout Ratio (DPR), Debt to Equity Ratio (DER), dan Price to Earning Ratio (PER) tidak berpengaruh pada perusahaan yang terdaftar di Jakarta Islamic Index (Khairi, 2012). Martani dan Khairuniza (2009) menemukan net profit margin dan price to book value (PBV) terbukti berpengaruh siginfikan terhadap Cumulative abnormal Return and market adjusted Return. Variabel debt to equity ratio dan working capital terbukti berpengaruh signifikan terhadap stock return pada perusahaan yang terdaftar di bursa efek Istambul (Büyüksalvarc dan Abdioglu, 2010). Hasil penelitian menunjukkan bahwa EVA dan ROE berhubungan signifikan dengan MVA, namun ROA tidak berhubungan signifikan dengan MVA pada perusahaan yang terdaftar di bursa saham Teheran. (Nakhaei dan Nik Intan, 2013).

\section{Hubungan Antara Profitabilitas dan Return \\ Saham Syariah}

ROE merupakan salah satu dari rasio profitabilitas yang digunakan untuk mengetahui tingkat pengembalian atas investasi yang ditanamkan oleh pemegang saham atau investor. ROE digunakan untuk mengukur tingkat pengembalian perusahaan atau efektivitas perusahaan dalam menghasilkan keuntungan. Rasio ini merupakan ukuran profitabilitas dilihat dari sudut pandang pemegang saham, semakin tinggi ROE menandakan bahwa perusahaan tersebut memiliki peluang untuk memberikan penghasilan yang besar bagi pemilik saham. Meningkatkan kemakmuran pemegang saham. Berdasarkan uraian diatas, maka hipotesis alternative dalam penelitian ini dapat dirumuskan sebagai berikut:

$\mathrm{H}_{1}$ : Profitabilitas berpengaruh positif terhadap return saham syariah.

\section{Hubungan antara Likuiditas dan Return Saham}

Menurut Syofyan (2010:301), rasio likuiditas merupakan rasio yang mengukur kemampuan perusahaan memenuhi kewajiban jangka pendeknya. Likuiditas perusahaan yang tinggi mengindikasikan bahwa perusahaan akan mampu memenuhi kewajibannya terhadap pemegang saham. Hal tersebut menunjukkan bahwa menemukan bahwa profitabilitas, turnover dan rasio pasar memiliki pengaruh signifikan terhadap return saham, maka hipotesis alternative dalam penelitian ini dapat dirumuskan sebagai berikut:

$\mathrm{H}_{2}$ : Likuiditas berpengaruh positif terhadap return saham syariah

\section{Hubungan antara Leverage dan Return Saham}

Debt to equity ratio (DER) adalah salah satu rasio leverage yang dapat menunjukkan kemampuan modal sendiri untuk memenuhi seluruh kewajibannya/ mengantisipasi hutang. Menurut (Syamsudin 2009:54) DER merupakan 
rasio yang dapat menunjukkan hubungan pinjaman jangka panjang yang diberikan oleh kreditur dengan jumlah modal sendiri yang diberikan oleh pemilik perusahaan. Jika laba per saham meningkat, maka akan berdampak pada meningkatkannya harga saham atau return saham, sehingga secara teoritis DER akan berpengaruh positif pada return saham. Berdasarkan uraian diatas, maka hipotesis alternatif dalam penelitian ini dapat dirumuskan sebagai berikut:

$\mathrm{H}_{3}$ : Leverage berpengaruh negative terhadap return saham syariah

\section{Hubungan Antara Arus Kas dan Return Saham}

Hubungan penelitian menunjukan bahwa unexpected cash inflows atau outflows dari operasi dalam periode tertentu akan mempengaruhi harga saham melalui pengaruhnya pada arus kas, sehingga diharapkan komponen arus kas dari operasi mempunyai hubungan yang signifikan dengan return saham (Lestari dan Halim, 2016; Putra dan Widyaningsih, 2016; Pratiwi dan Putra, 2015). Kinerja pasar dapat dilihat dari tingkat pengembalian investasi (return) jangka panjang perusahaan atau return saham. Berdasarkan uraian diatas, maka hipotesis alternatif dalam penelitian ini dapat dirumuskan sebagai berikut: $\mathrm{H}_{4}$ : Arus kas operasi berpengaruh positif terhadap return saham syariah

Dari keseluruhan teoritik tentang pengaruh profitabilitas, likuiditas, leverage, dan arus kas operasi terhadap return saham syariah yang telah dipaparkan di atas, maka dapat dibuat suatu kerangka pemikiran yang dapat digambarkan sebagai berikut :

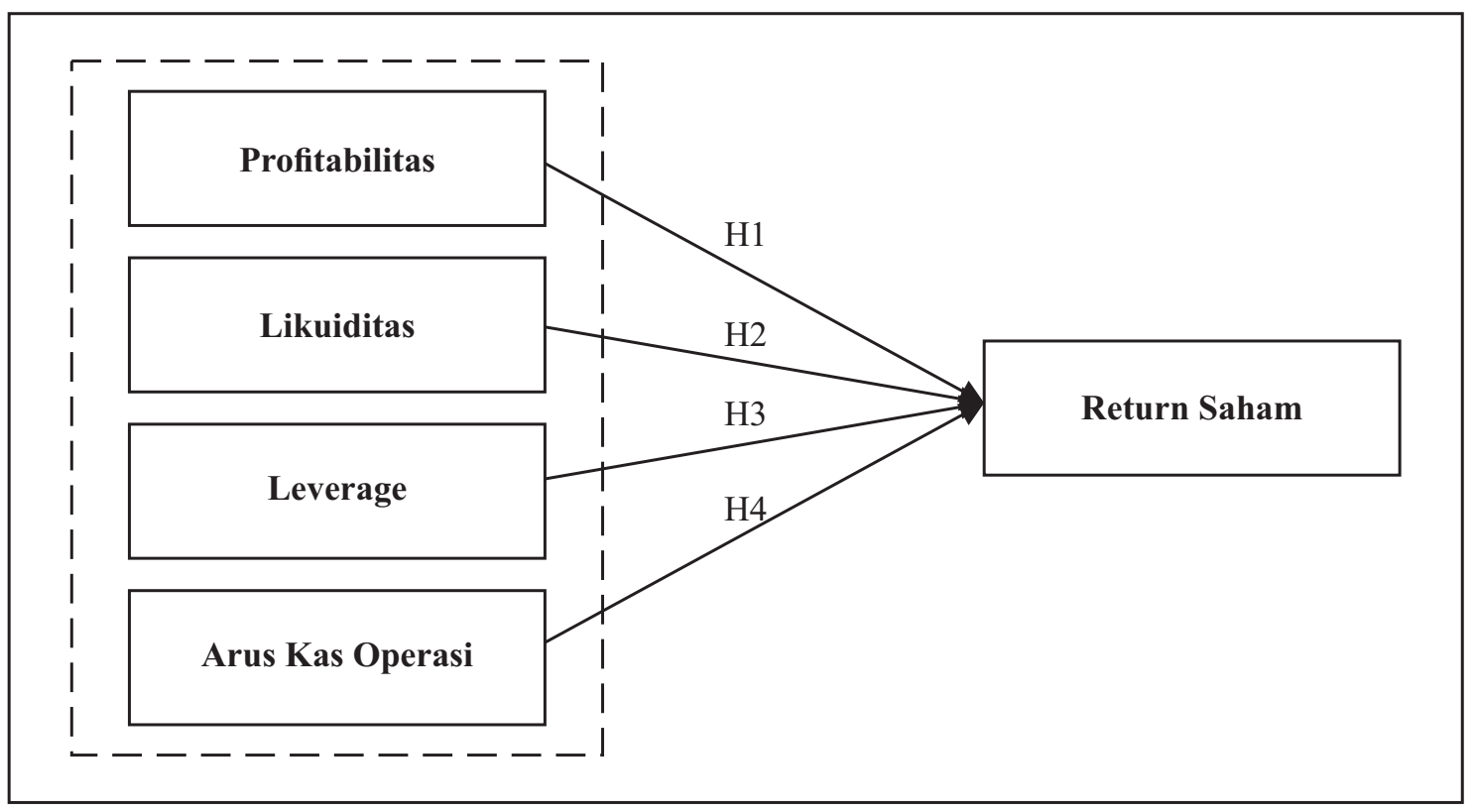

Gambar 2. Kerangka Pemikiran

\section{Metode}

Penelitian ini termasuk kedalam jenis penelitian kuantitatif yang mana data kuantitatif tersebut adalah data sekunder. Data sekunder yang digunakan berupa data laporan keuangan auditan perusahaan yang terdaftar di Jakarta Islamic Index tahun 2009-2015 idx.co.id.
Populasi dalam penelitian ini yaitu perusahaan yang terdaftar di Jakarta Islamic Index (JII) dari tahun 2009 sampai 2015. Pemilihan sampel dalam penelitian ini mengunakan metode purposive sampling. 
Tabel 3. Seleksi Sampel

\begin{tabular}{clc}
\hline No. & \multicolumn{1}{c}{ Kriteria Sampel } & Jumlah \\
\hline 1 & $\begin{array}{l}\text { Perusahaan yang tergabung di Jakarta Islamic Index yang terdaftar di JII } \\
2\end{array}$ & $\begin{array}{l}\text { Perusahaan yang tidak secara berturut-turut melaporkan data keuangan } \\
\text { perusahaannya. }\end{array}$ \\
3 & $\begin{array}{l}\text { Perusahaan yang dijadikan objek penelitain } \\
4\end{array}$ & 29 \\
& $\begin{array}{l}\text { Jumlah data sampel tahun 2009-2015 (29 sampel perusahaan property dikali } \\
7 \text { tahun) }\end{array}$ & 203 \\
5 & Data penelitian & 203 \\
\hline
\end{tabular}

Metode pengumpulan data yang dilakukan pada penelitian ini adalah metode dokumentasi, yaitu data yang diperoleh dari berbagai dokumen atau literatur yang berkaitan dengan permasalahan yang sedang diteliti. Setelah dokumentasi, dikumpulkan, diseleksi, dan kemudian diolah. Dalam penelitian ini, variabel dependennya adalan Return Saham merupakan bahwa pengembalian saham akan berasal dari dividen ditambah keuntungan modal (capital gain). Variabel independen terdiri dari Profitabilitas, likuiditas, leverage, dan arus kas operasi. Profitabilitas merupakan kemampuan perusahaan dalam menghasilkan laba dalam hubungannya dengan penjualan, asset dan modal sendiri. Likuiditas merupakan kemampuan perusahaan dalam melunasi kewajiban jangka pendek perusahaan. Rasio leverage ini digunakan untuk mengukur keseimbangan proporsi antara aset yang didanai dari kreditor (utang) dan yang didanai oleh pemilik perusahaan (ekuitas). Arus kas ukuran perusahaan menunjukkan seberapa besar perusahaan dilihat dari aktivitas operasi meliputi penerimaan dan pengeluaran yang dimiliki.

Tabel 4. Operasionalisasi Variabel

\begin{tabular}{|c|c|c|c|c|}
\hline No. & $\begin{array}{l}\text { Variabel } \\
\text { Penelitian }\end{array}$ & Dimensi & Indikator & Skala \\
\hline 1 & $\begin{array}{l}\text { Return saham } \\
\text { Syariah } \\
\text { (Y) }\end{array}$ & $\begin{array}{l}\text { Merupakan capital gain yaitu } \\
\text { selisih antara closing price pada } \\
\text { periode t dengan closing pice } \\
\text { periode sebelumnya (t-1) }\end{array}$ & $\mathrm{R}_{\mathrm{it}}=-\frac{\mathrm{P}_{\mathrm{it}}}{\mathrm{P}_{\mathrm{it}-1}}-\mathrm{P}_{\mathrm{it-1}}$ & Rasio \\
\hline 2 & $\begin{array}{l}\text { Profitabilitas } \\
\qquad\left(\mathrm{X}_{1}\right)\end{array}$ & Return on Asset (ROA) & $R O A=\frac{\text { Net Income }}{\text { Total Asset }}$ & Rasio \\
\hline 3 & $\begin{array}{l}\text { Likuidasi } \\
\left(\mathrm{X}_{2}\right)\end{array}$ & $\begin{array}{l}\text { Rasio antara aktiva lancar terhadap } \\
\text { hutang lancar }\end{array}$ & $C R=\frac{\text { Current Asset }}{\text { Current liabilities }}$ & Rasio \\
\hline 4 & $\begin{array}{l}\text { Leverage } \\
\quad\left(\mathrm{X}_{3}\right)\end{array}$ & Debt Equtry Ratio (DAR) & DER $=\frac{\text { Total Liabilities }}{\text { Total Asset }}$ & Rasio \\
\hline 5 & $\begin{array}{l}\text { Cash Flow } \\
\quad\left(\mathrm{X}_{4}\right)\end{array}$ & Operating Activitas & $\begin{array}{l}\text { Nilai bersih arus kas } \\
\text { operasi }\end{array}$ & Rasio \\
\hline
\end{tabular}

Pengujian terhadap hipotesis dalam penelitian ini dilakukan dengan analisis multivariate menggunakan regresi linear berganda (multiple regression). Analisis regresi linier bergadna digunakan untuk mengetahui atau memperoleh gambaran mengenai pengaruh variabel independen pada variabel dependen dan bertujuan untuk mengestimasi dan atau memprediksi rata-rata populasi atau nilai ratarata variabel dependen berdasarkan nilai variabel independen yang diketahui. Teknik analisis ini menggunakan uji asumsi klasik pada variabel bebasnya (Ghozali, 2013).

1. Statistik Deskriptif 
Statistik deskriptif digunakan untuk memberikan gambaran deskripsi suatu data yang dilihat dari rata-rata (mean), standar deviasi, varian, maksimum, minimum (Ghozali, 2013).

2. Pengujian Asumsi Klasik

a. Uji Normalitas

Uji normalitas digunakan untuk mengetahui apakah dalam suatu model regresi, baik variabel dependen dan variabel independen memiliki residual yang distribusi normal. Uji normalitas dalam penelitian ini dilakukan dengan menggunakan uji One Sample Kolmogorov-Smirnov Test dengan melihat angka signifikansi dan plot probabilitas normal. Apabila nilainya lebih besar daripada level signifikasi penelitian (0.05), maka tidak terjadi masalah normalitas.

b. Uji Multikolinearitas

Menurut Ghozali (2013) uji multikolinearitas adalah uji untuk mengetahui hubungan yang bermakna korelasi (langsung) antara setiap variabel independen dalam suatu regresi. Model regresi yang baik seharusnya tidak terjadi korelasi di antara variabel independen. Pengujian ini dapat dilakukan dengan menggunakan Variance Inflation Factor (VIF). Jika nilai VIF $>10$, maka variabel tersebut mempunyai persoalan multikolinearitas dengan variabel independen.

c. Uji Autokorelasi

Autokorelasi adalah keadaan dimana variabel gangguan pada periode tertentu berkorelasi dengan variabel lain, dengan kata lain variabel gangguan tidak random. Untuk menguji apakah hasil-hasil estimasi model regresi tersebut tidak mengandung korelasi serial diantara disturbance term-nya, maka dipergunakan Durbin Watson
Statistik (koefisien korelasi Durbin Watson).

d. Uji Heteroskedastisitas

Menurut Ghozali (2013:105) pengujian heteroskedastisitas dalam model regresi dilakukan untuk mengetahui apakah dalam model regresi terjadi ketidaksamaan varian dari residual satu pengamatan ke pengamatan yang lain. Jika varian dari residual satu pengamatan ke pengamatan lain tetap, maka disebut homoskedastisitas dan jikaberbedadisebutheteroskedastisitas. Model regresi yang baik adalah yang homoskedastisitas atau tidak terjadi heteroskedastisitas. Kebanyakan data cross-section mengandung situasi heteroskedastisitas karena data ini menghimpun data yang mewakili berbagai ukuran (kecil, sedang dan besar).

3. Pengujian Hipotesis

a. Koefisien Korelasi (R), $R$ Square, dan Adjusted R Square

Pengujian ini digunakan untuk mengetahui tingkat ketepatan yang terbaik dalam analisis regresi dalam hal ini ditunjukkan oleh besarnya koefisien determinasi. Koefisien determinasi (R2) digunakan untuk mengetahui prosentase pengaruh variabel independen terhadap variabel dependen. Dari sini akan diketahui seberapa besar variabel independen akan mampu menjelaskan variabel dependennya, sedangkan sisanya dijelaskan oleh sebab-sebab lain di luar model. Nilai koefisien R2 mempunyai interval nol sampai satu $(0 \leq \mathrm{R} 2 \leq 1)$. Semakin besar R2 (mendekati 1), semakin baik hasil untuk model regresi tersebut dan semakin mendekati 0 , maka variabel independen secara keseluruhan tidak dapat menjelaskan variabel dependen. Untuk menghindari 
bias, maka digunakan nilai Adjusted R2, karena Adjusted R2 dapat naik atau turun apabila satu variabel independen ditambahkan dalam model.

b. Uji F

Uji F untuk mengetahui apakah model regresi tersebut dapat digunakan untuk memprediksi atau dapat juga dikatakan variabel independen secara bersamasama memiliki mempengaruhi terhadap variabel dependen.

c. Uji t

Uji tberguna untuk menguji signifikansi apakah variabel independen (X) berpengaruh secara nyata atau tidak. Untuk melakukan uji hipotesis biasanya digunakan uji t-test atau uji signifikan, level signifikansi dalam penelitian ini sebesar $5 \%(0,05)$.

Model yang digunakan dalam penelitian ini adalah :

$$
\begin{aligned}
& \mathrm{Y}=\mathrm{a}+\mathrm{b} 1 \mathrm{X} 1+\mathrm{b} 2 \mathrm{X} 2+\mathrm{b} 3 \mathrm{X} 3+\mathrm{b} 4 \mathrm{X} 4+\mathrm{e} \\
& \text { Keterangan : } \\
& \mathrm{Y}=\text { Return Saham } \\
& \mathrm{a}=\text { Konstanta } \\
& \mathrm{X} 1=\text { Profitabilitas } \\
& \mathrm{X} 2=\text { Likuiditas } \\
& \mathrm{X} 3=\text { Leverage } \\
& \mathrm{X} 5=\text { Arus Kas Operasi }
\end{aligned}
$$

$$
\begin{array}{ll}
\mathrm{b} 1-\mathrm{b} 2 & =\text { Koefisien regresi } \\
\mathrm{e} & =\text { Error }
\end{array}
$$

\section{Hasil Penelitian dan Pembahasan}

Berdasarkan hasil perhitungan selama tahun pengamatan pada periode 2009-2015 pada sektor perusahaan yang listing dan terdaftar di Jakarta Islmic index, maka dapat diketahui bahwa Profitabilitas, Likuiditas, Leverage, dan Arus Kas Operasi terhadap Return Saham Syariah mengalami pergerakan yang berfluktuatif. Variabel ROA, memiliki nilai terendah sebesar -0,64 diperoleh XL Axiata Tbk pada tahun 2014. dan yang tertinggi sebesar 1,258 diperoleh Unilever Indonesia Tbk pada tahun 2013. Rasio lancar (current ratio / CR) memiliki nilai terendah sebesar 0,334 diperoleh XL Axiata Tbk pada tahun 2009. pada tahun 2014 dan yang tertinggi sebesar 9,717 diperoleh Media Nusantara Tbk. pada tahun 2011 DER memiliki nilai terendah sebesar 0,154 diperoleh Indocement Tunggal Prakasa Tbk. pada tahun 2009 dan tertinggi sebesar 6,722 diperoleh Indofood CBP Sukses Makmur Tbk. pada tahun 2015 yaitu sebesar -2.711 CFO memiliki nilai terendah yang diperoleh Lippo Karawaci Tbk. pada tahun 2015 dan nilai tertinggi sebesar 4.322 diperoleh Telekomunikasi Indonesia Tbk. Hasil pengujian hipotesis dirangkum pada table berikut.

Tabel 5. Rangkuman Hasil Pengujian

\begin{tabular}{lrrrr}
\hline Keterangan & \multicolumn{1}{c}{ B } & Std. Error & \multicolumn{1}{c}{ t-hitung } & \multicolumn{1}{c}{ Sig. } \\
\hline Profitability & -128.173 & 93.990 & -1.364 & .175 \\
Liquidity & -22.151 & 13.612 & -1.627 & .106 \\
Leverage & -.813 & 26.621 & -.031 & .976 \\
Cashflow & -77.375 & 16.228 & -4.768 & .000 \\
Constant & 1336.780 & 246.229 & & \\
F-hitung & 8.651 & & & \\
Sig. F & 0.000 & & & \\
\hline
\end{tabular}

Berdasarkan tabel diatas, persamaan model regresi linear berganda dalam penelitian ini dapat dinyatakan sebagai berikut :

$$
\text { Return } \text { saham }=1336.780-128.173 \text { ROA }-22.152 \text { CR }-0,02 \text { LVR }-77.375 \text { CFO }+\varepsilon
$$


Nilai koefisien korelasi dari Profitability adalah sebesar $-128,73$. Hal tersebut berarti apabila nilai koefisien regresi variabel independen lainnya tetap (tidak berubah), maka perubahan 1 (satu) satuan Profitability akan menaikkan return saham syariah sebesar 0,000 satuan. Nilai t-hitung $(-1,364)$ dan nilai signifikansi $(0,175)$ lebih besar dari 0,05 maka Ha ditolak, yang berarti return on asset (ROA) tidak berpengaruh secara signifikan terhadap return saham

Nilai koefisien korelasi dari liquidity adalah sebesar -22,151. Hal tersebut berarti apabila nilai koefisien regresi variabel independen lainnya tetap (tidak berubah), maka perubahan 1 (satu) satuan Liquidity akan menaikkan return saham sebesar $-22,151$ satuan. Nilai t-hitung $(-1,627)$ dan nilai signifikansi Liquidity $(0,106)$ lebih besar dari 0,05 maka Ha ditolak, yang berarti Liquidity tidak berpengaruh secara signifikan terhadap return saham syariah.

Nilai koefisien korelasi dari Levarage adalah sebesar $-0,813$. Hal tersebut berarti apabila nilai koefisien regresi variabel independen lainnya tetap (tidak berubah), maka perubahan 1 (satu) satuan Leverage akan menaikkan return saham syariah sebesar $-0,813$ satuan. Nilai t-hitung $(-0.031)$ dan nilai signifikansi Levarage $(0,976)$ lebih besar dari 0,05 maka Ha ditolak, yang berarti Leverage tidak berpengaruh secara signifikan terhadap return saham syariah.

Nilai koefisien korelasi dari Cash Flow adalah sebesar $-77,375$. Hal tersebut berarti apabila nilai koefisien regresi variabel independen lainnya tetap (tidak berubah), maka perubahan 1 (satu) satuan Cash Flow akan menaikkan return saham syariah sebesar $-77,375$ satuan. Nilai t-hitung $(-4,768)$ dan nilai signifikansi Cash Flow $(0,000)$ lebih kecil dari 0,05 maka Ha diterima, yang berarti Cash Flow berpengaruh secara signifikan terhadap return saham syariah.

\section{Pengaruh Profitabilitas terhadap return saham syariah}

Hasil koefisien regresi menunjukkan bahwa Profitabilitas tidak mempunyai pengaruh secara signifikan return saham syariah. Hasil ini mengindikasikan bahwa besarnya Profitabilitas yang dihasilkan perusahaan tidak berpengaruh signifikan terhadap return saham syariah.

Tidak adanya hubungan yang signifikan dari ROA dengan Return saham syariah menunjukkan bahwa banyak perusahaan yang mendapatkan ROA yang lebih tinggi pada saat yang sama justru cenderung tidak memiliki return saham tahunan yang lebih besar, walaupun memiliki return saham nya mengalami kenaikan tetapi kenaikan nya tidak signifikan. Hal ini ditunjukkan dengan nilai koefisien regresi yang memiliki arah koefisien negatif. Kondisi ini dapat menjelaskan bahwa reaksi yang ditunjukkan oleh investor terhadap informasi profitabilitas tidak sesuai sebagaimana yang diharapkan. Atau dalam hal ini reaksi investor pada akhir tahun tidak mengikuti profitabilitas yang diperoleh perusahaan pada akhir tahun. Hal ini dapat dikarenakan tidak semua investor sudah mengetahui informasi profitabilitas yang diperoleh perusahaan pada akhir tahun karena pada waktu tersebut sebenarnya laporan keuangan dalam proses audit sehingga informasi yang diterima investor belum sepenunya reliabel. Hasil penelitian ini mengindikasikan bahwa para investor tidak semata-mata menggunakan Profitabilitas sebagai ukuran dalam menilai kinerja perusahaan untuk memprediksi total return saham syariah di pasar modal (terutama di Jakarta Islamic Index (JII)).

Kondisi ini tidak konsisten dan berbeda dengan hasil penelitian Triani (2012) yang menyatakan bahwa hasil penelitian menemukan faktor makro ekonomi yang diwakili oleh volume of transactions, dan interest rates secara bersama-sama berpengaruh signifikan terhadap return saham syariah dan secara parsial hanya volume of transactions yang berpegaruh signifikan terhadap return saham syariah. Hasil 
riset juga tidak mendukung hasil penelitian Judulha dan Kusumawardhani (2013) serta Raningsih dan Putra (2015) yang membuktikan bahwa profitabilitas mempengaruhi imbal hasil saham.

\section{Pengaruh likuiditas terhadap return saham syariah}

Hasil koefisien regresi menunjukkan bahwa likuiditas mempunyai tidak pengaruh signifikan terhadap return saham syariah. Hasil penelitian ini menunjukkan bahwa besarnya pengaruh likuiditas saham terhadap return saham syariah pada perusahaan yang ada di Jakarta Islamic Index dengan pengaruh likuiditas saham yang negatif ini berarti dengan tingkat likuiditas saham yang kecil tidak dapat memberikan tingkat return saham yang tinggi. Oleh karena itu Trading Volume Activity (TVA) tidak bisa memberikan tingkat return yang tinggi karena perusahaan yang ada di Jakarta Islamic Index tidak terus aktif diperdagangkan di lantai Jakarta Islamic Index sehingga investor perlu berfikir dahulu dan menganalisa untuk menginvestasikan dananya di Jakarta Islamic Index. Hasil penelitian ini tidak sejalan terhadap penelitian-penelitian yang dilakukan oleh penelitian Martani dan Khairuniza (2009) serta Raningsih dan Putra (2015) menyatakan bahwa profitabilitas, turnover dan rasio pasar memiliki pengaruh signifikan terhadap return saham.

\section{Pengaruh leverage terhadap return saham syariah}

Hasil koefisien regresi menunjukkan bahwa leverage mempunyai tidak pengaruh secara signifikan terhadap return saham. Hasil penelitian ini menunjukkan bahwa besar nya nilai rasio leverage mempengaruhi turunnya return saham karena bila rasio leverage besar maka perusahaan tersebut tidak liquid karena rasio utang terhadap modalnya sangat besar. Investor akan memprediksi adanya kemungkinan perusahaan tersebut tidak mampu membayar seluruh hutang jangka pendek dan jangka panjangnya, maka investor tidak tertarik untuk membeli saham perusahaan yang mempunyai rasio utang besar, dampak tidak ketertarikan investor berdampak pada harga saham perusahaan tersebut turun, penurunan harga saham tersebut akan membuat return saham tersebut turun.

Hal ini tidak sejalan terhadap penelitianpenelitian yang dilakukan oleh penelitian Raningsih dan Putra (2015) menemukan bukti empiris bahwa DER menpunyai hubungan positif dan signifikan terhadap return saham.

\section{Pengaruh arus kas operasi terhadap return saham syariah}

Hasil koefisien regresi menunjukkan bahwa arus kas operasi mempunyai pengaruh secara signifikan return saham syariah. Hasil ini mengindikasikan bahwa besarnya arus kas operasi yang dihasilkan perusahaan berpengaruh signifikan terhadap return saham syariah. Arus kas operasi mempunyai relevansi nilai bagi investor untuk memprediksi arus kas di masa mendatang. Ketika nilai arus kas dari aktivitas operasi bernilai positif yang berarti arus kas operasi masuk lebih besar dari arus kas operasi keluar, maka hal ini menunjukkan bahwa kinerja perusahaan berjalan dengan lancar, dan hal ini akan meyakinkan para investor utuk melakukan investasi karena dengan lancarnya kinerja perusahaan, maka return saham yang didapatkan oleh investor akan besar pula. Selain itu, perusahaan yang arus kas operasinya bernilai positif mengidentifikasi bahwa perusahaan dapat menghasilkan kas yang cukup untuk kegiatan usahanya, akan hal ini merupakan sinyal yang bagus untuk memberikan deviden yang diharapkan oleh investor. Sehingga perusahaan mempunyai arus kas operasi yang bagus dan menambah keyakinan investor terhadap return saham.

Kondisi ini tidak konsisten dan berbeda dengan hasil penelitian Oktorina dan Hutagaol (2009) yang menyatakan bahwa hasil penelitian menemukan arus kas kegiatan operasi memiliki informasi tambahan selain yang dijelaskan oleh 
laba kepada pasar, namun hasil temuan tersebut disebabkan oleh data periode tahun dan belum dilakukan penanganan terhadap data yang outlier. Dan mereka menemukan bahwa arus kas kegiatan operasi dan agregat akrual memiliki hubungan dengan abnormal return. sedangkan hasil penelitian Oktorina dan Hutagaol (2009) menunjukkan bahwa komponen arus kas dari operasi dan pendaan memiliki hubungan dengan return saham dan berpengaruh negatif terhadap return saham.

\section{Simpulan, Keterbatasan, dan Implikasi Hasil Penelitian}

Berdasarkan hasil pengujian Profitabilitas, Likuiditas, Leverage, dan Arus Kas Operasi terhadap Return Saham Syariah baik secara parsial maupun simultan pada perusahaan yang tergabung di Jakarta Islamic Index-2015, maka dapat disimpulkan Profitabilitas tidak berpengaruh terhadap return saham ini bertolak belakang dengan hipotesis yang menyatakan bahwa ROA mempunyai pengaruh signifikan terhadap return saham. Sedangkan Likuiditas tidak berpengaruh terhadap return saham ini bertolak belakang dengan hipotesis yang menyatakan bahwa likuiditas bahwa likuiditas mempunyai pengaruh signifikan. Leverage tidak berpengaruh secara signifikan terhadap return saham hal ini tidak sejalan dengan hipotesis yang menyatakan bahwa DER mempunyai hubungan positif dan signifikan terhadap return saham. arus kas operasi berpengaruh signifikan terhadap return saham ini tidak sejalan dengan hipotesis yang menyatakan bahwa hasil penelitian menemukan arus kas kegiatan operasi memiliki informasi tambahan selain yang dijelaskan oleh laba kepada pasar.

Saran yang dapat digunakan bagi pihak yang ingin melanjutkan penelitian ini adalah bagi regulator tentunya agar dapat menentukan segala kebijakan yang terkait dengan mempertimbangkan faktor-faktor yang lain selain variabel dalam penelitian ini dengan tujuan dapat mempermudah aspek-aspek penelitian sehingga penelitian selanjutnya dapat memperkecil gap. Bagi peneliti selanjutnya dapat menambahkan faktor akuntansi lainnya, karateristik Industri, serta faktor non-akuntansi lainnya seperti tingkat suku bunga, dan kurs, jumlah sampel yang diambil lebih banyak dan luas dengan menambahkan jenis-jenis perusahaan go public yang terdaftar di Jakarta Islamic Index dengan periode pengamatan yang lebih lama. Bagi akademisi tentunya dapat mengembangkan dan merumuskan teori dengan mempertimbangkan beberapa hasil penelitian yang telah ada sehingga penelitian selanjutnya dapat lebih terarah lagi. Dan bagi pelaku usaha dapat menentukan keputusan serta strategi-strategi yang diperlukan dalam pengembangan penelitian selanjutnya serta selain mempertimbangkan aspek fundamental, sebaiknya mempertimbangkan juga aspek-aspek lain.

\section{Daftar Referensi}

Büyüksalvarci, A., \& Abdioglu, H. (2010). Corporate Governance, Financial Ratios and Stock Returns: An Empirical Analysis of İstanbul Stock Exchange (ISE). International Research Journal of Finance and Economics, 57, 70-81.

Ghozali, Imam, (2013). Aplikasi Analisis Multivariat dengan Program IBM SPSS 21. Edisi 7, Penerbit Universitas Diponegoro, Semarang.

Hartono, J., (2008). Teori Portofolio dan Analisis Investasi. Edisi Kelima, BPFE, Yogyakarta. Julduha, N., \& Kusumawardhani, I. (2013). Pengaruh Net Profit Margin, Current Ratio, Debt To Asset Ratio Dan Tingkat Suku Bunga Terhadap Beta Saham Syariah Pada Perusahaan Yang Terdaftar Di Jakarta Islamic Index. Buletin Studi Ekonomi, 18(2).144-152.

Khairi, M. S. (2012). Analisis Pengaruh Karakteristik Perusahaan Terhadap Return 
Saham Syariah Yang Tergabung Di Jakarta Islamic Index Pada Periode 20082011. Jurnal Ilmiah Mahasiswa FEB, 1(1).

Lestari, A. P., \& Halim, A. (2016). Pengaruh Arus Kas Operasi, Price Earning Ratio, dan Earning Per Share Terhadap Return Saham Perusahaan Otomotif di Bursa Efek Indonesia Tahun 2014-2015. Jurnal Riset Mahasiswa Akuntansi, 4(2).1-16.

Martani, D., \& Khairurizka, R. (2009). The effect of financial ratios, firm size, and cash flow from operating activities in the interim report to the stock return. Chinese Business Review, 8(6), 44.

Nakhaei, H., \& Nik Intan, N. B. (2013). The relationship between economic value added, return on assets, and return on equity with market value added in Tehran Stock Exchange (TSE). In Proceedings of Global Business and Finance Research Conference .pp. 28-29.

Natarsyah S. (2002). Analisis Pengaruh beberapa Faktor Fundamental dan Risiko Sistematik terhadap Harga Saham. Bunga Rampai Kajian Teori Keuangan. Jogjakarta: BPFE.
Oktorina, M., \& Hutagaol, Y. (2009). Analisis arus kas kegiatan operasi dalam mendeteksi manipulasi aktivitas riil dan dampaknya terhadap kinerja pasar. Jurnal Riset Akuntansi Indonesia, 12, 1-14

Pratiwi, T. W., \& Putra, I. W. (2015). Pengaruh Rasio Keuangan, Ukuran Perusahaan, Arus Kas Aktivitas Operasi Pada Return Saham. E-Jurnal Akuntansi, 11(2), 531546.

Putra, Y. R., \& Widyaningsih, M. (2016). Pengaruh Laba Akuntansi, Komponen Arus Kas, Dan Dividend Yield Terhadap Return Saham (Studi Pada Perusahaan Sektor Pertambangan Di Bursa Efek Indonesia Periode 2012-2014). Jurnal Riset Akuntansi dan Keuangan, 4(2), 1047-1058.

Raningsih, N. K., \& Putra, I. M. P. D. (2015). Pengaruh Rasio-Rasio Keuangan Dan Ukuran Perusahaan Pada Return Saham. E-Jurnal Akuntansi, 582-598.

Triani, L. F. (2012). Faktor-Faktor yang Mempengaruhi Perubahan Indeks Harga Saham di Jakarta Islamic Index selama tahun 2011. Semnas Fekon: Optimisme Ekonomi Indonesia 2013, Antara Peluang dan Tantangan. Jakarta. 